Article

\title{
Reliability and Degradation of Solar PV Modules-Case Study of 19-Year-Old Polycrystalline Modules in Ghana
}

\author{
David A. Quansah 1,2,3,*, Muyiwa S. Adaramola ${ }^{1}$, Gabriel Takyi ${ }^{2,3}$ and Isaac A. Edwin ${ }^{2,3}$ \\ 1 Renewable Energy Group, Faculty of Environmental Sciences and Natural Resource Management, \\ Norwegian University of Life Sciences (NMBU), Ås (1432), Norway; muyiwa.adaramola@nmbu.no \\ 2 The Brew-Hammond Energy Centre, College of Engineering, Kwame Nkrumah University of Science and \\ Technology (KNUST), PMB, University Post Office, Kumasi, Ghana; gabrieltakyi@yahoo.co.uk (G.T.); \\ edwinadjei@gmail.com (I.A.E.) \\ 3 Department of Mechanical Engineering, College of Engineering, Kwame Nkrumah University of Science \\ and Technology (KNUST), PMB, University Post Office, Kumasi, Ghana \\ * Correspondence: david.ato.quansah@nmbu.no; Tel.: +47-90-56-10-63
}

Academic Editor: Manoj Gupta

Received: 3 May 2017; Accepted: 12 May 2017; Published: 22 May 2017

\begin{abstract}
Fourteen (14) rack-mounted polycrystalline modules installed on the concrete roof of the solar energy applications laboratory at the Kwame Nkrumah University of Science and Technology (KNUST) in Ghana, a hot humid environment, were assessed after 19 years of continuous outdoor exposure. The physical state of the modules was documented using a visual inspection checklist. They were further assessed by current-voltage (I-V) characterization and thermal imaging. The modules were found to be in good physical state, except some bubbles on front side and minor discolouration/corrosion at edge of the cells. Compared with reference values, the performance decline of the modules observed over the exposure period was: nominal power $\left(\mathrm{P}_{\mathrm{nom}}\right), 21 \%$ to $35 \%$; short circuit current $\left(\mathrm{I}_{\mathrm{sc}}\right), 5.8 \%$ to $11.7 \%$; open circuit voltage $\left(\mathrm{V}_{\mathrm{oc}}\right) 3.6 \%$ to $5.6 \%$ and $11.9 \%$ to $25.7 \%$ for fill factor (FF). It is hoped that this study will provide some helpful information to project developers, manufacturers and the research community on the long-term performance of PV modules in Ghana.
\end{abstract}

Keywords: solar PV; module; degradation; characterization; I-V Curve

\section{Introduction}

The phenomenal and sustained growth of solar photovoltaics (PV) in recent years is well-documented [1-9]. Indeed, this growth extends to other renewable energy technologies such as wind, bioenergy, hydropower and geothermal. The drivers for this growth are widely acknowledged to include, climate policy, technology improvements and energy security considerations. Research and development (R\&D) efforts have paid off in the form of increased efficiencies at both cell and module levels. For example, cell efficiencies reported in major laboratories for crystalline silicon have increased from $13 \%$ in the 1970 s to over $26 \%$ in 2016 [10,11], doubling in the period, and thus approaching the theoretical thermodynamic limit of 34\% (Shockley-Queisser limit) $[12,13]$ for single crystal silicon cells at standard test conditions. Advances in thin-film and multi-junction cell technologies have been even more rapid. The cell-to-module efficiencies for these cell technologies have also improved to $99 \%$ (in 2015) and is projected to exceed 103\% by 2026 because of improvement in light management techniques [14].

As research laboratories and industry players focus on improving solar-to-electric conversion efficiencies, there is increasing acknowledgement of the need for data on the performance of systems that have already been deployed across the various climates and geographical regions of the world. 
A characteristic feature of solar PV (and other renewables) is the high upfront cost per installed power. Once installed, reliable performance and durability of the system enables it to generate electricity $(\mathrm{kWh})$, which represents a benefit to the investor/system owner. Reliability is understood as the probability that an item, in this case the solar PV module, will continue to perform its intended function without failure for a specified period of time under stated conditions [15,16]. Durability, on the other hand, has to do with how long the product will last under normal operating conditions [17].

For the solar PV investor, reliable operation of the PV modules and their durability as per warranty conditions, are important for the realization of the expected return on investment. Module manufacturers, similar to other product manufacturers, attempt to assure buyers of their products by providing warranties. The warranties on PV modules have evolved from 5 years in the 1980s, through 10-20 years in the 1990s to current industry standard practice of $80 \%$ of peak power for 25 years [18]. Some manufacturers provide 2-stage (and other multi-stage) warranties. These warranties are typically in the range of $90 \%-95 \%$ peak power in the first $5-10$ years and thereafter, $80 \%-87 \%$ of peak power up to year 25 [19]. REC Solar [20], for example, provides a $97 \%$ performance guarantee on its modules within the first year of exposure and $80.2 \%$ of peak power by the end of the 25 th year.

For current standard 25 year warranty ( $80 \%$ of peak power) to hold, modules must, on the average, degrade at not more than $0.8 \%$ /year (Figure 1). However, industry players are seeking to extend warranty periods to 30 years [21], which would imply a maximum average annual performance decline of no more than $0.65 \%$ (Figure 1 ).

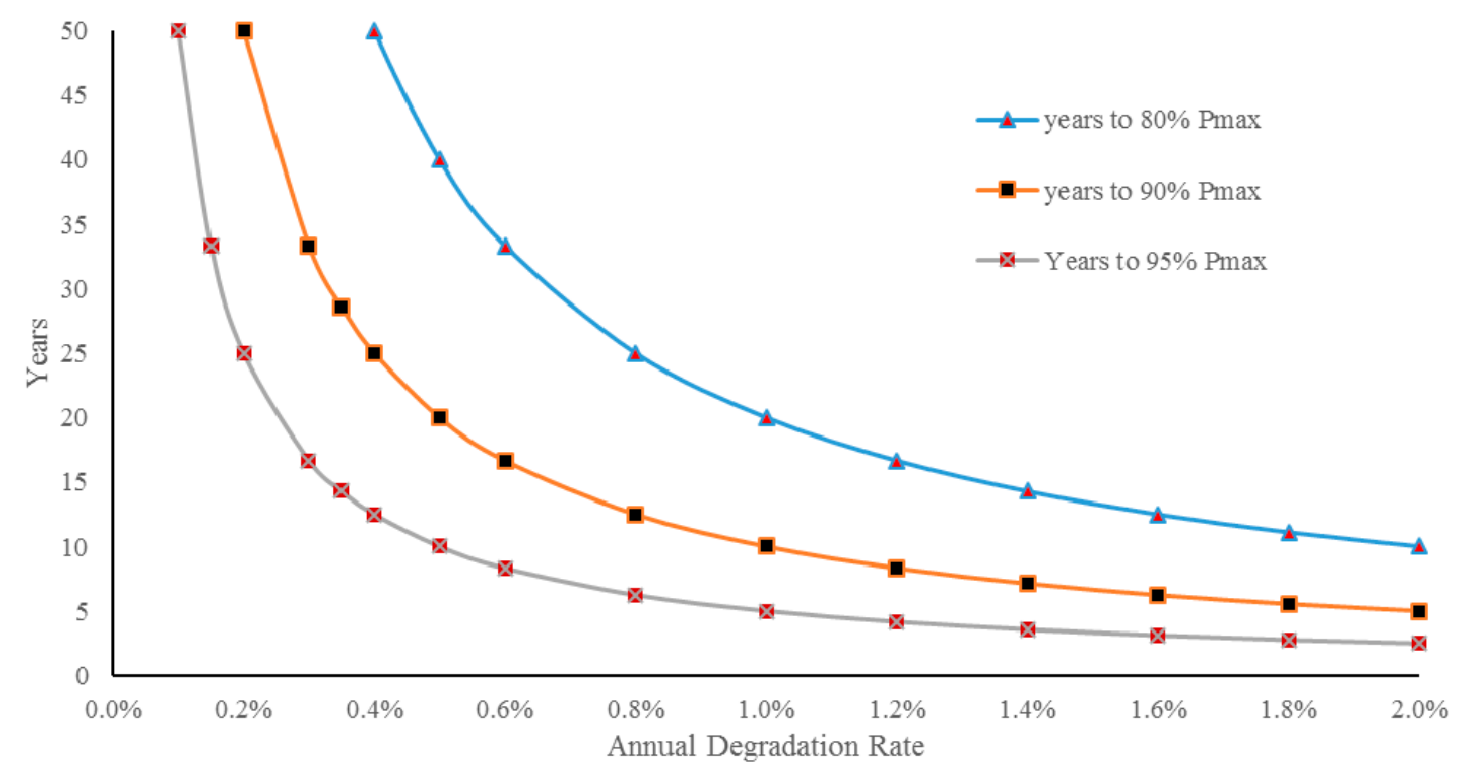

Figure 1. Module warranty periods and degradation rates.

Solar PV warranties typically encounter two major hurdles. First, is the enforceability of the warranties [22]. This is largely attributable to the rapidly evolving landscape that has led to the extinction of many manufacturers, with others filing for bankruptcy. This extinction was most noticeable in the period 2010-2013, when, in the US alone, over 50 companies either collapsed or filed for bankruptcy protection [23]. Warranties provided by defunct companies on PV modules sold therefore become difficult to enforce, particularly if the need for warranty claims arise after official liquidation. To address this first problem with the warranties, some manufacturers are now providing insurance-backed warranties [24-27]. These insurance products are, however, certain to add to the cost of modules to the buyer.

The second difficulty with the warranties is the more fundamental question of physical basis. Current testing and qualification regimes such as the IEC 61215 [28] for crystalline Silicon modules and IEC 61646 [29] for thin film modules employ techniques such as accelerated ageing and stress 
tests with the view to detecting the presence of known failure or degradation modes in the intended environments [30]. These qualifications tests can however not predict or guarantee product life under field conditions. They are indeed not designed for such a purpose [30,31]. Qualification tests instead seek, among other answers, to find design and process flaws and have been credited with significantly reducing infant mortality among PV modules [32]. It has been suggested [18], that recent studies based on field exposure is providing some basis for and validation of 25-year warranties; however, an overwhelming majority of modules have hardly lasted 25 years on the field to prove the validity of the warranties. Figure 2 shows that, over $80 \%$ of modules installed today have been installed in the last 5 to 6 years.

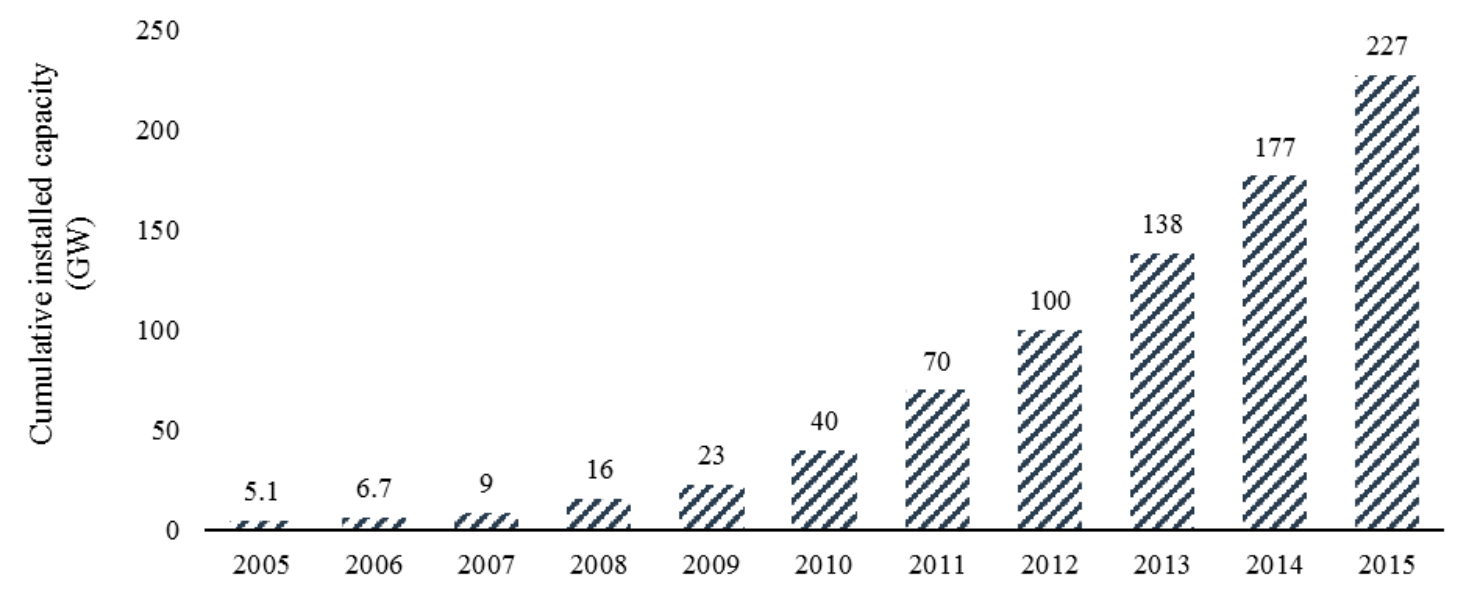

Figure 2. Global module installations over the years. Data REN21 [8].

To compound this problem further, the technologies themselves are undergoing significant material level changes. For example, [33-35] reported that crystalline Silicon (c-Si) wafer thickness has reduced from $400 \mu \mathrm{m}$ in 1990 to $180 \mu \mathrm{m}$ in 2015, while silicon usage has declined from 16g/Wp in 2004 to less than $6 \mathrm{~g} / \mathrm{Wp}$ in 2015. The metallization is also moving away from silver to less expensive options such as copper, nickel and zinc [34].

Therefore, monitoring and assessment of fielded modules provide useful insight and feedback for module manufacturers and R\&D institutions and reduces uncertainties for solar PV investors. A number of researchers have undertaken, over the years, to study the long-term outdoor performance, degradation and failure of solar PV modules around the world. Notable authors in this area include Lorenzo et al. [36], Bandou et al. [37], Ndiaye et al. [38], Jordan and Kurtz [18], Quintana et al. [39], Skoczek [40], Skoczek et al. [41], Kahoul et al. [42] and Ferrara and Daniel [43]. The literature identifies major causes and modes of module degradation and failure to include [18,39]: degradation of packaging materials, loss of adhesion, degradation of cell/module interconnects as a result of thermomechanical fatigue, degradation due to moisture intrusion and degradation of semiconductor device [39]. These defects tend to result in reduced module output, safety issues and sometimes complete failure. Nevertheless, as noted by Jordan et al. [44], it may be surmised, that, degradation in performance characteristics of modules have some dependence on local conditions and climate zone. Yet, there are no reports on degradation rates and failure modes of PV modules in many climate zones [44,45]. Indeed, as demonstrated by authors such as Jordan et al. [44] and Phinekarides et al. [45], who compiled globally reported degradation rates and overlaid them on global maps (using the Koppen climate classification), there is very little reported from Africa, with nothing at all in the vast majority of climate classifications.

According to Peel et al. [46], Africa's climate comprises mainly of three (3) of the Koppen-Geiger climate types-A, B and C. Ghana's climate is classified as tropical climate (A) of the monsoon (Am) and savanna with dry winter $(\mathrm{Aw})$ types. This implies that the average temperature of the coolest month of 
the year is above $18{ }^{\circ} \mathrm{C}$. In terms of precipitation, the tropical monsoon climate's driest month records less than $60 \mathrm{~mm}$ of precipitation but the precipitation is greater than or equal to $\mathrm{h}$.

Where

$$
h=100-\frac{\text { Total annual precipitation (in } \mathrm{mm} \text { ) }}{25}
$$

Precipitation in tropical savanna climate is less than $60 \mathrm{~mm}$ in the driest month and also less than $h$ (as defined in Equation (1)) [46]. Further microclimate sub-classifications of the country have also been made based on agro-ecological characteristics of various zones and is used by organizations such as the UN Food and Agriculture Organization (FAO) [47]. These sub-classifications are: Rain Forest, Deciduous Forest, Forest-Savannah Transition, Coastal Savannah and Northern (Interior) Savannah which comprises Guinea and Sudan Savannahs [47].

It should be noted, however, that, whereas the Koppen-Geiger classification scheme is based on temperature and precipitation, for solar PV performance and durability issues additional parameters such as humidity, temperature variation (thermal cycling), altitude and air salinity are important as well [43]. For consistency and comparability of analysis, consolidation of climate categories sometimes becomes necessary. In the work of Jordan et al. [44], tropical climates such as Aw and Af are broadly classified together with Cfa (Temperate hot summer without dry season) and consolidated as hot and humid. This present work adopts this climate categorization. Another climate categorization of interest is that which was used for the All-India Survey of Photovoltaic Module Degradation: 2013 [48].

This paper seeks to contribute to filling this gap (long-term performance of PV modules and degradation in Africa) and presents results of assessment conducted on an 19-year old polycrystalline solar PV installation at the Kwame Nkrumah University of Science and Technology (KNUST) in Ghana.

\section{Materials and Methods}

\subsection{Site Description and Climate}

As shown in Figure 3, Kumasi is a hot and humid climate with average daily temperature ranging from $24.4{ }^{\circ} \mathrm{C}$ in July to $27.8{ }^{\circ} \mathrm{C}$ in March and relative humidity of $65 \%$ in January to $83.5 \%$ in July [49]. Hence, accordingly, Kumasi is climate condition can be classified as Aw using Koppen classification. This climate would be categorized as "warm and humid" per classifications used in [48].

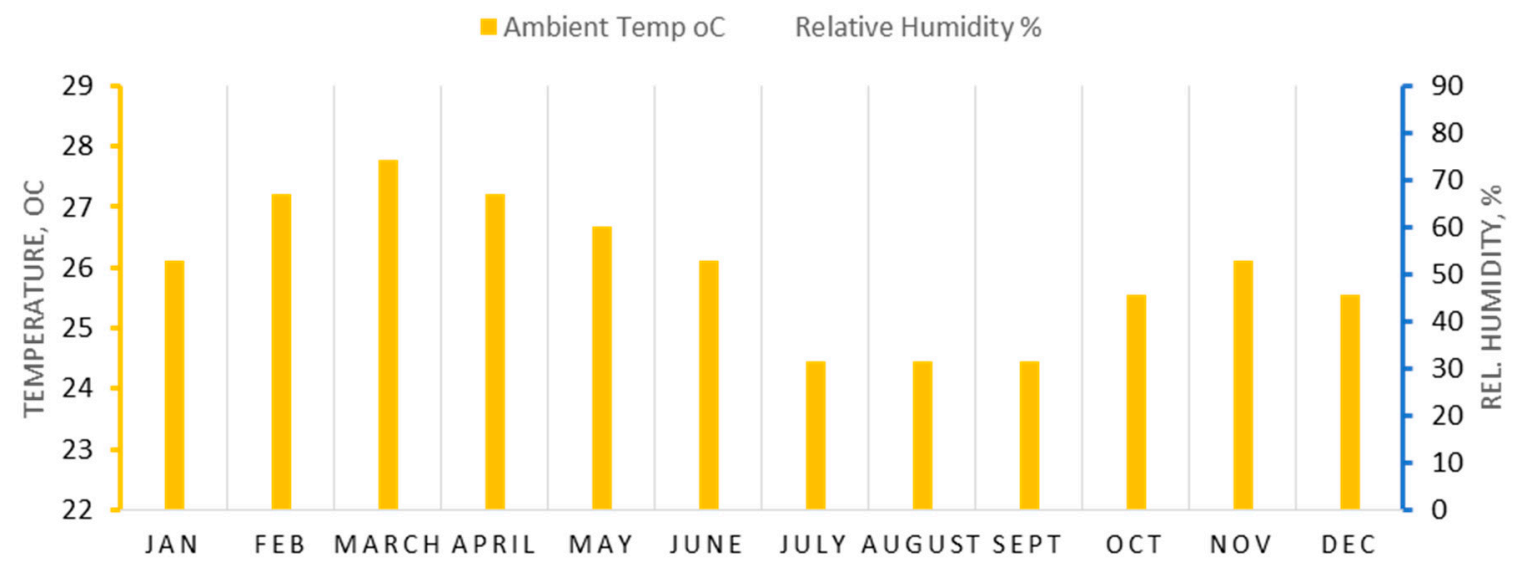

Figure 3. Monthly Average Temperature and Humidity in Kumasi. Data from [49].

Daily solar irradiation on horizontal surface in Kumasi ranges from $3.35 \mathrm{kWh} / \mathrm{m}^{2}$ in August to $5.09 \mathrm{kWh} / \mathrm{m}^{2}$ in April and monthly precipitation in the year varies from a low of $25 \mathrm{~mm}$ in December to a high of $218 \mathrm{~mm}$ in June (Figure 4). Wind speeds are generally low and ranges from average $1.5 \mathrm{~m} / \mathrm{s}$ to $2.6 \mathrm{~m} / \mathrm{s}$ at this location [49]. 


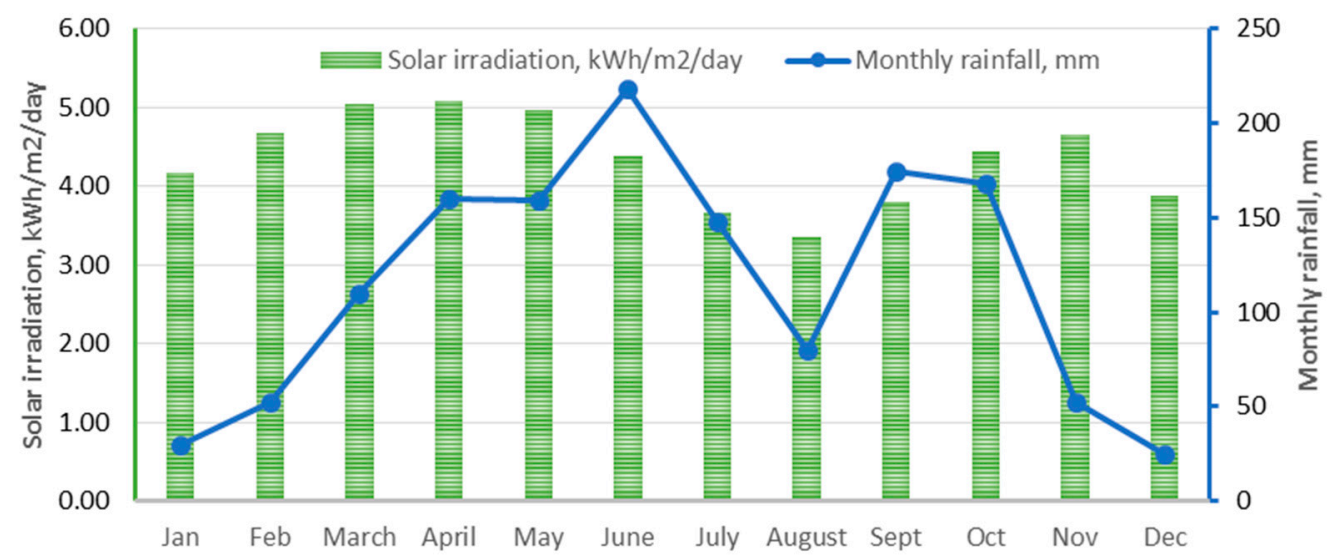

Figure 4. Daily solar irradiation and precipitation for Kumasi. Data from [49,50].

\subsection{Description of Installation}

The system under study was installed in 1998 and comprises of fourteen (14) ASE-50-PWX-D modules, manufactured by ASE GmbH (Putzbrunn, Germany). They were initially installed as part of joint project on solar-driven centrifugal pumps between the Institute of Machine Design, Hydraulic Turbomachinery and Hydrodynamics at the Technical University of Berlin (Germany) and the Department of Mechanical Engineering, Kwame Nkrumah University of Science and Technology (Ghana). The modules have for some time now been used in off-grid mode and charges a $400 \mathrm{Ah}$ which provides power to selected loads at the Solar lab at the College of Engineering.

The system is mounted on a metallic frame on top of a concrete roof with about $1 \mathrm{~m}$ clearance above the roof and hence, ensures good ventilation of the modules. Each module comprises 36 cells and has nominal power of $49 \mathrm{~W}$ (a total of $686 \mathrm{Wp}$ ). The module material comprises tempered glass at the front $(3.1 \mathrm{~mm})$, EVA (ethylene vinyl acetate) encapsulant, polymer backsheet and aluminium frame [51]. Performance parameters of the modules are shown in Table 1.

Table 1. Reference module parameters.

\begin{tabular}{cc}
\hline Parameter & Value \\
\hline Nominal Power $\left(\mathrm{P}_{\mathrm{nom}}\right), \mathrm{W}$ & 49.50 \\
Short-circuit current $\left(\mathrm{I}_{\mathrm{sc}}\right), \mathrm{A}$ & 3.10 \\
Open-circuit voltage $\left(\mathrm{V}_{\mathrm{oc}}\right), \mathrm{V}$ & 21.60 \\
Current at maximum power point $\left(\mathrm{I}_{\mathrm{mpp}}\right), \mathrm{A}$ & 2.85 \\
Voltage at maximum power point $\left(\mathrm{V}_{\mathrm{mpp}}\right), \mathrm{V}$ & 17.40 \\
Efficiency & $10.3 \%$ \\
\hline
\end{tabular}

The modules were qualified under the CEC ESTI (European Solar Test Installation) 503 Standard. The cell design comprises two bus bars and 40 grid lines, organized in a rectangular pattern around four (4) centres on the two bus bars (Figure 5). In addition to the rectangular grid patterns, four (4) grid lines are also observed to run across the cells in both horizontal and vertical directions (Figure 5).

The modules are oriented toward south with a fixed inclination of approximately $15^{\circ}$ to the horizontal. For the purpose of the assessment and measurements, the modules were labelled from PWX1 to PWX 14 as shown in Figure 6.

During the measurements, the modules were electrically isolated to permit access to the terminals of the modules. Even though there was no cleaning schedule in place for the modules, the rains had done some cleaning of the module surface during the period of measurement. Nonetheless, to further eliminate impact of dust on the measurement, the module surfaces were cleaned with clean water and allowed to dry before measurements were made. 


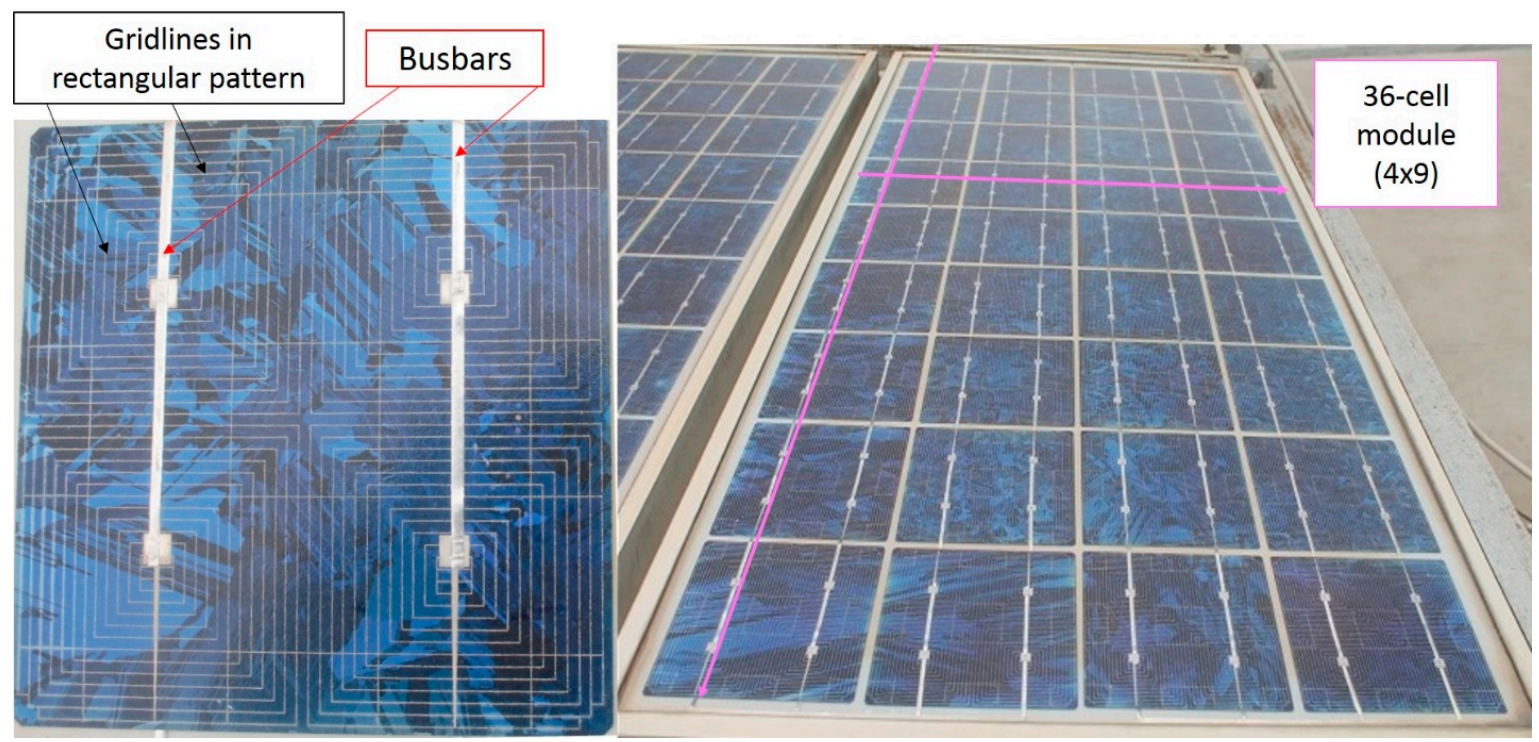

Figure 5. A photograph of the solar cell (left) showing its metallization and the module (right) showing number of cells.

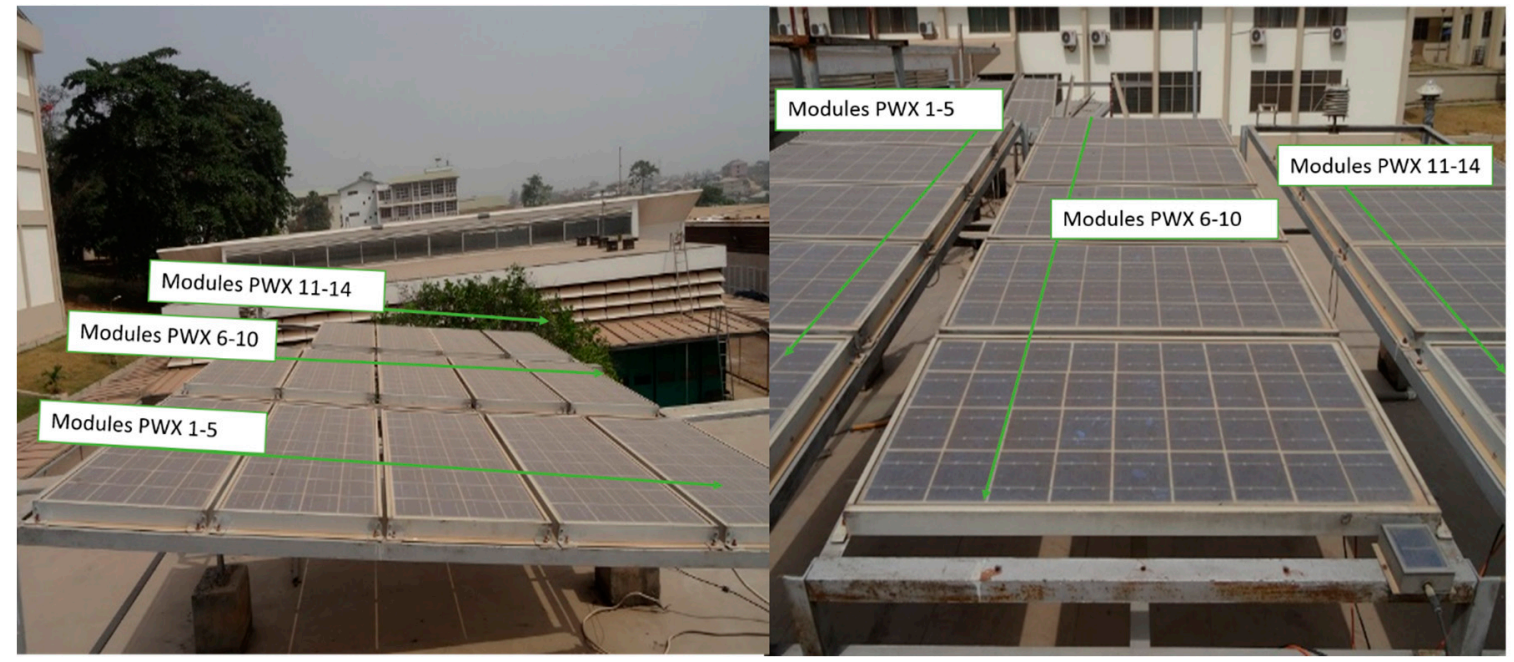

Figure 6. Picture of installation from different views showing modules labelled as PWX 1-14.

\subsection{Inspection and Measurements}

Field assessment of solar PV modules usually employs techniques such as visual and physical inspection, I-V (current-voltage) characterization, bypass diode test, insulation testing and thermal imaging to help detect defects in the modules [41]. Some defects, such as micro-cracks in cell structure may not be visible to the eye and require more advanced techniques such as electroluminescence imaging to detect. However, the I-V curve tracing is the most widely used technique in outdoor electrical characterization of solar PV modules [52].

In this study, three methods, which are visual inspection, I-V characterisation and thermal imaging were used. The visual inspection of the modules was undertaken using the widely-applied field visual inspection template by NREL/IEA [32]. This sought to systematically document any visually observable defects on the various components of the modules (such as front glass, back sheets, junction boxes, metallization, encapsulation and frames) and interconnections following 18 years of outdoor exposure. 
Many known PV module defects (encapsulant browning, solder bond degradation, hot spot formation, etc.) also lead to changes such as increased series resistance, lowered shunt resistance, low transmittance of front glass and encapsulant (and optical decoupling) which tend also have characteristic signatures on I-V curves. The I-V characterization of the modules under study was undertaken using a TRI-KA I-V curve tracer. The TRI-KA IV tracer works together with TRI-SEN which measures irradiance, module temperature and module inclination angle. In-plane irradiance and module temperature are necessary for the translation of the current-voltage measurements to other reference conditions, such as STC (Standard Test Conditions-i.e., $25^{\circ} \mathrm{C}, 1000 \mathrm{~W} / \mathrm{m}^{2}$ and AM 1.5). Module current is known to be a strong function of irradiance, while voltage on the other hand, has a stronger dependence on temperature. The TRI-SEN maintains a wireless communication with the TRI-KA during the measurements.

The TRI-KA I-V tracer has a voltage and current measurement range of 1-1000 V, and 0.1-15 A, respectively, with uncertainty of $\pm 1 \%$ (for both current and voltage). The TRI-SEN measures temperature in the range $0-100{ }^{\circ} \mathrm{C}\left( \pm 3 \%\right.$ uncertainty) and irradiance in the range $100-1200 \mathrm{~W} / \mathrm{m}^{2}$ ( $\pm 5 \%$ uncertainty).

The key parameters used for assessment include the nominal power $\left(\mathrm{P}_{\text {nom }}\right)$, short-circuit current $\left(\mathrm{I}_{\mathrm{sc}}\right)$, open circuit voltage $\left(\mathrm{V}_{\mathrm{oc}}\right)$ and fill factor $(\mathrm{FF})$. It must be noted, that maximum power $\left(\mathrm{P}_{\max }\right)$, which is the product of $I_{s c}$ and $V_{o c}$ is never generated, as the I-V curve (see Figure 7) is never rectangular. The peak power may therefore be viewed as a fraction of the maximum power. This fraction is the fill factor.

A Fluke ${ }^{\circledR}$ TI400 thermal camera was used to obtain thermal images of the modules in forward bias mode at $\mathrm{I}_{\mathrm{sc}}$. The emissivity of the camera was set to 0.85 since the module surface is glass. This was to help assess temperature inhomogeneity and possible hotspots in the modules.

\subsection{Calculations and Data Analysis}

A modified version of IEC 60891 (Procedures for temperature and irradiance corrections to measured I-V characteristics.) I-V data translation method, developed by the Joint Research Centre (JRC) of the European Commission and applied in the German 1,000 Roofs Solar Programme [53,54] was used. The equations are presented below (Equations (2)-(5)):

$$
\begin{gathered}
I_{S C, 2}=I_{S C, 1}\left[1+\alpha\left(T_{2}-T_{1}\right)\right] \frac{G_{2}}{G_{1}} \\
V_{O C, 2}=V_{O C, 1}\left[1+a \ln \frac{G_{2}}{G_{1}}+b \cdot\left(T_{2}-T_{1}\right)\right] \\
I_{2}=I_{1}\left(\frac{I_{S C, 2}}{I_{S C, 1}}\right) \\
V_{2}=V_{1}+\left(V_{O C, 2}-V_{O C, 1}\right)+R_{S}\left(I_{1}-I_{2}\right)
\end{gathered}
$$

where: $I$ is current (A); $I_{s c}$ is short-circuit current (A); $G$ is irradiance $\left(\mathrm{W} / \mathrm{m}^{2}\right) ; T$ is module temperature $\left({ }^{\circ} \mathrm{C}\right), V$ is voltage $(\mathrm{V})$ and $V_{o c}$ is open-circuit voltage $(\mathrm{V})$. In these equations, subscripts 1 and 2 refer respectively to measured values and values at reference conditions. The constant parameters and their default values, which are valid for crystalline silicon, are defined and given as:

- $\quad \alpha$ is a dimensionless temperature coefficient of $I_{s c}$ (default value is 0 )

- $\quad b$ is dimensionless temperature coefficient of $V_{o c}$ (default value is -0.004 )

- $a$ is dimensionless irradiance correction factor (default value is 0.06 ) and

- $R_{s}$ is series resistance $(\Omega)$ (default value is 0 )

Although a number numeric and algebraic approaches exist (e.g., IEC [55], Smith et al. [56], Tsuno et al. [57] and Marion [58]) for translating I-V data from measured to desired reference conditions 
(such as STC), many of these require the determination of coefficients, which in turn require controlled conditions such as constant irradiance and constant temperature; conditions which are difficult to obtain under field conditions, making the equations difficult to implement. The approach proposed by JRC therefore presents a balance between accuracy and practicability and has uncertainty of about $4 \%$.

Standard manufacturer reference electrical parameters are normally reported at STC conditions. However, outdoor conditions differ, and sometimes the irradiance is well below this reference. Work by Anderson [59], has shown that translating to STC from low irradiance values and high temperature comes with lower levels of accuracy. In this present study, effort was therefore made to obtain I-V measurements at irradiance levels that were as close as possible to $1000 \mathrm{~W} / \mathrm{m}^{2}$. The standardization could in principle also be undertaken to other reference conditions, such as to the nearest irradiance level for which reference I-V data is available.

The I-V characteristic curve of the ASE-50-PWX-D module at different irradiance levels was obtained from PVSyst solar PV module database (Figure 7) [51] due to the fact that the manufacturer label on the module only showed the peak power. PVSyst uses the well-known 1-diode model to generate I-V curves. For reasons of completeness and consistency of data and following the example of Abete et al. [18], even though the manufacturer label on the module has $49 \mathrm{~W}$ as peak power rating, $49.5 \mathrm{~W}$ (with short-circuit current of $3.1 \mathrm{~A}$ and open circuit voltage $21.6 \mathrm{~V}$ ) based on the 1-diode model of PVSyst is used in this paper as the baseline. This will result in the assessment of power degradation being slightly overstated (by approximately $1 \%$ ). The use of models to simulate baselines for module degradation studies is discussed further by [52]. The decline in key characteristics of the modules was computed by comparing the standardized performance data with the baseline values.

PV module: ASE, ASE-50-PWX-K/D-a

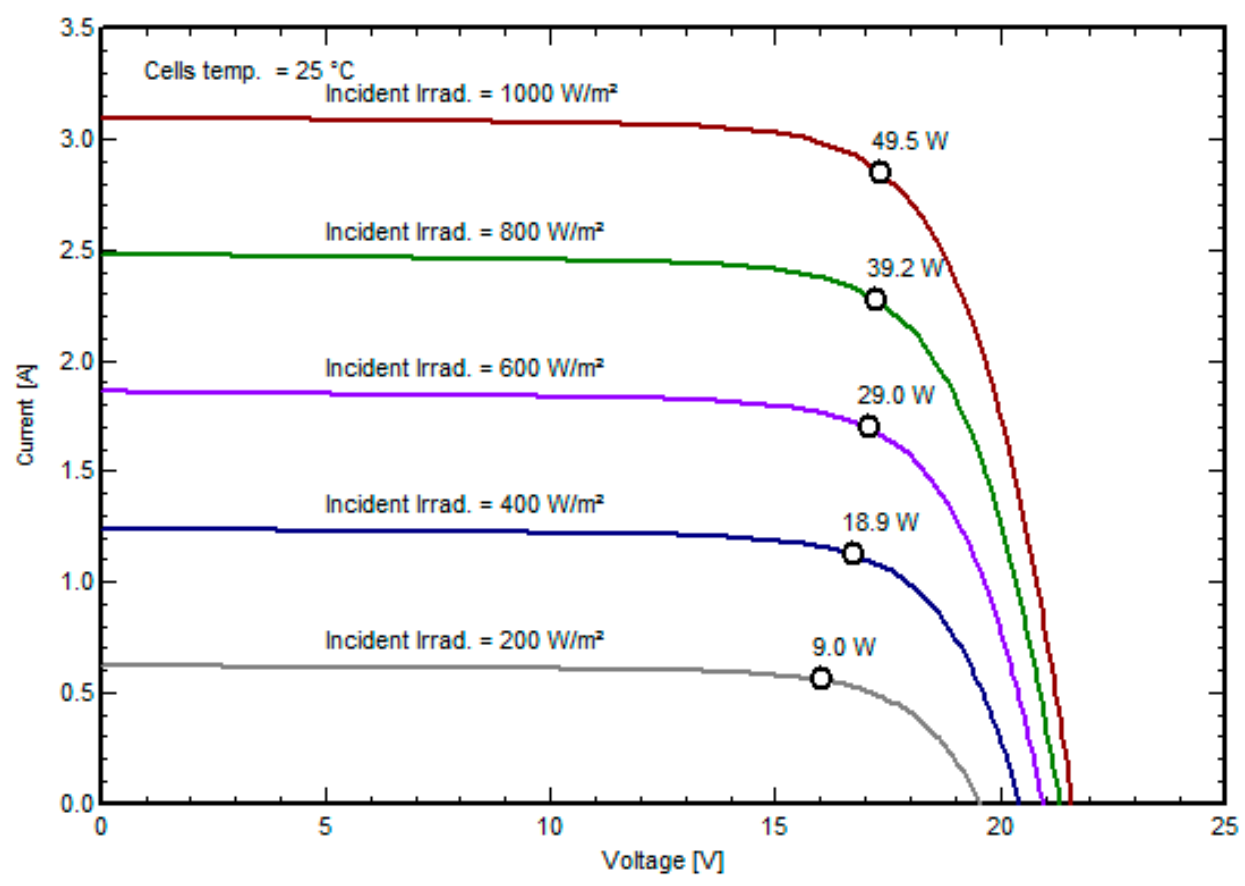

Figure 7. I-V curve of ASE-50-PWX-D module at different irradiance levels. Data-PVSyst SA [51].

\section{Results and Discussion}

\subsection{Visual and Physical Inspection}

The visual inspection documented the visually observable condition of the modules. The summary is presented in Table 2. Accompanying pictures are shown in Figures 8-11. Generally, no major visually observable defects were seen on the front glass, backsheets, wires/connectors, the junction box, frame 
and metallization. Some minor corrosion/discolouration at the edge of some cells was also observed (Figure 9).

Table 2. Visual inspection observations.

\begin{tabular}{|c|c|}
\hline Component & Observation(s) \\
\hline Front Glass & $\begin{array}{l}\text { Front glass was smooth and dusty prior to cleaning with water; no damage or cracks } \\
\text { were observed. Minor occurrence of bubbles were observable on the front side of the } \\
\text { module (Figure 8). }\end{array}$ \\
\hline Backsheet & $\begin{array}{l}\text { Minor discoloration observable from front glass (Figure } 8 \text { ) - this might be due to } \\
\text { moisture ingress. Generally was like new. No wavy texture was observed, no chalking, } \\
\text { burn marks or other damage was visible. }\end{array}$ \\
\hline Wires/Connectors & no embrittlement or burns was observed. \\
\hline Junction Box & $\begin{array}{l}\text { Intact and well-attached, no loss of adhesion was observed, Figure } 9 \text { (opened by } \\
\text { authors during study). }\end{array}$ \\
\hline Frame & $\begin{array}{l}\text { Minor discoloration was observed; no corrosion was found; frame adhesive was not } \\
\text { visible and showed no signs of degradation; the bottom section of the frame was soiled } \\
\text { and had accumulated over the years. Figure } 10\end{array}$ \\
\hline Metallization & Bus-bars and cell interconnects showed no burns, discoloration or corrosion. Figure 10 \\
\hline PV Cell & $\begin{array}{l}\text { The cells were observed to be in good condition. Light discolouration }(<5 \%) \text { could be } \\
\text { seen at the edge of some of the cells when the image is magnified. }\end{array}$ \\
\hline
\end{tabular}

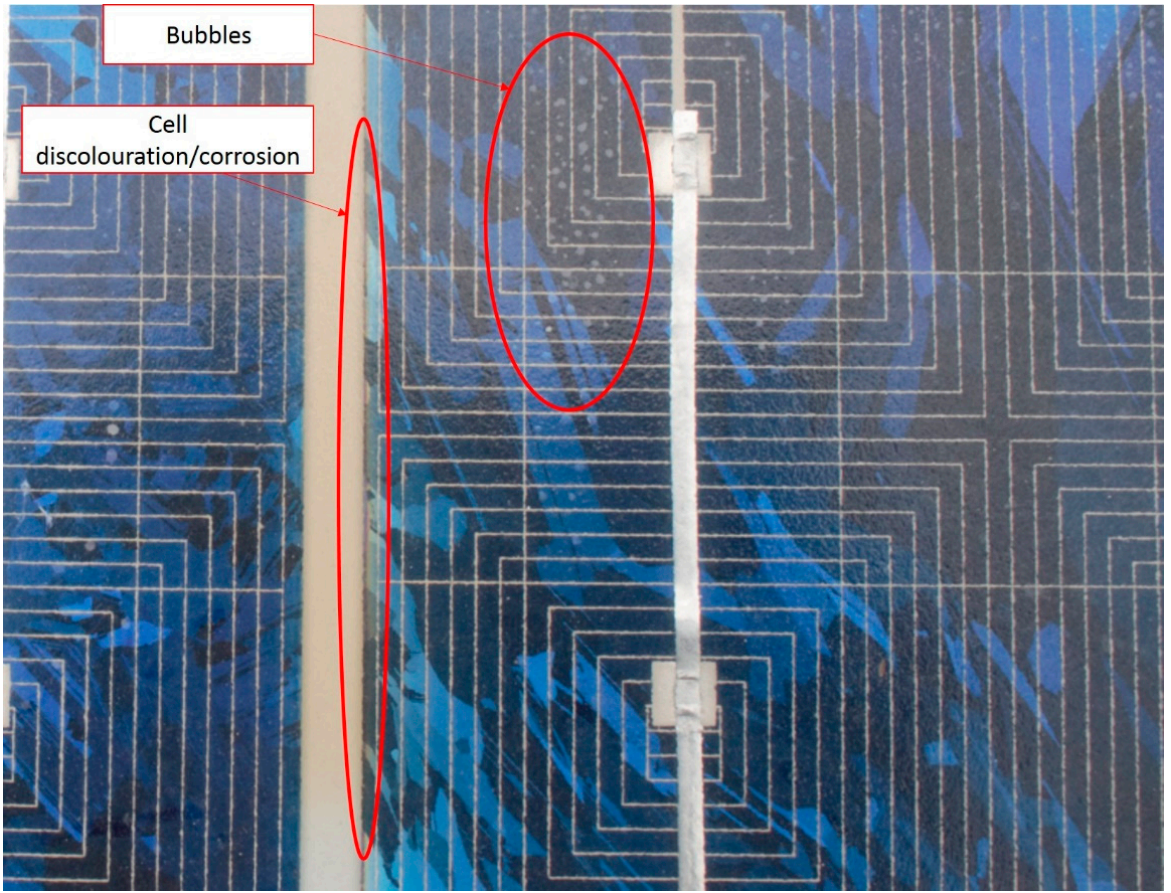

Figure 8. Minor discolouration of backsheet (Observable from front glass). Busbars and fingers in good condition. 


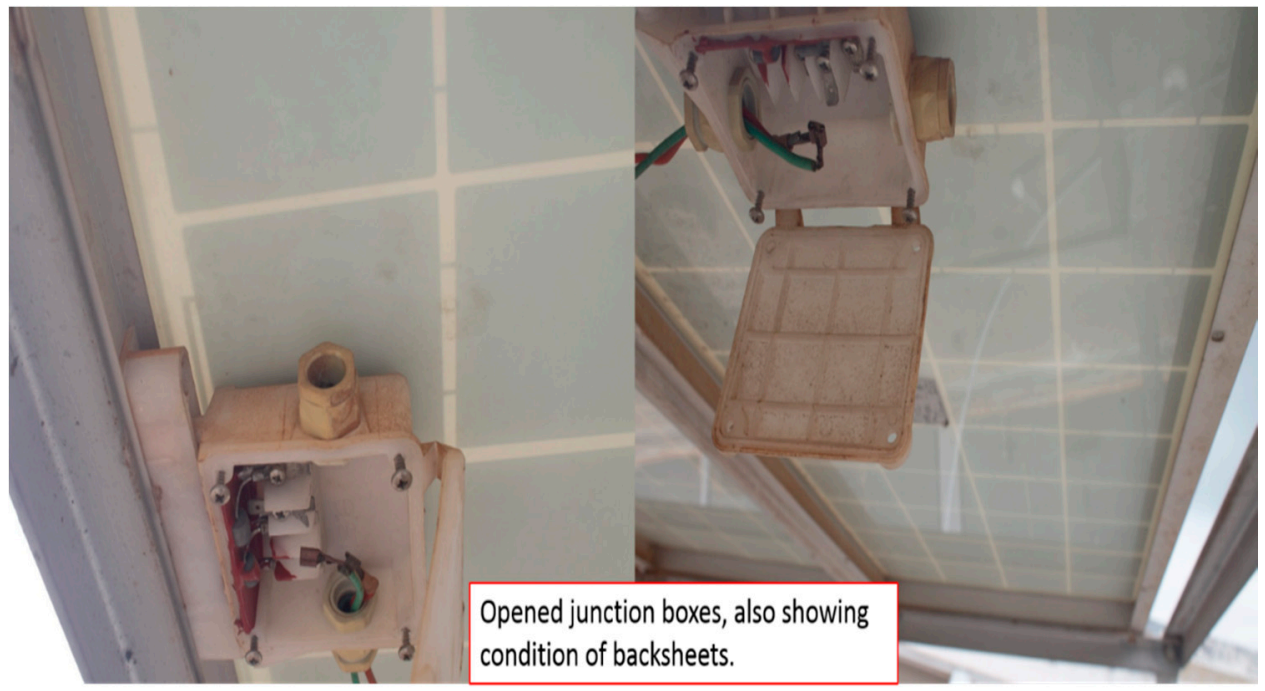

Figure 9. Junction box of modules, also showing backsheet.

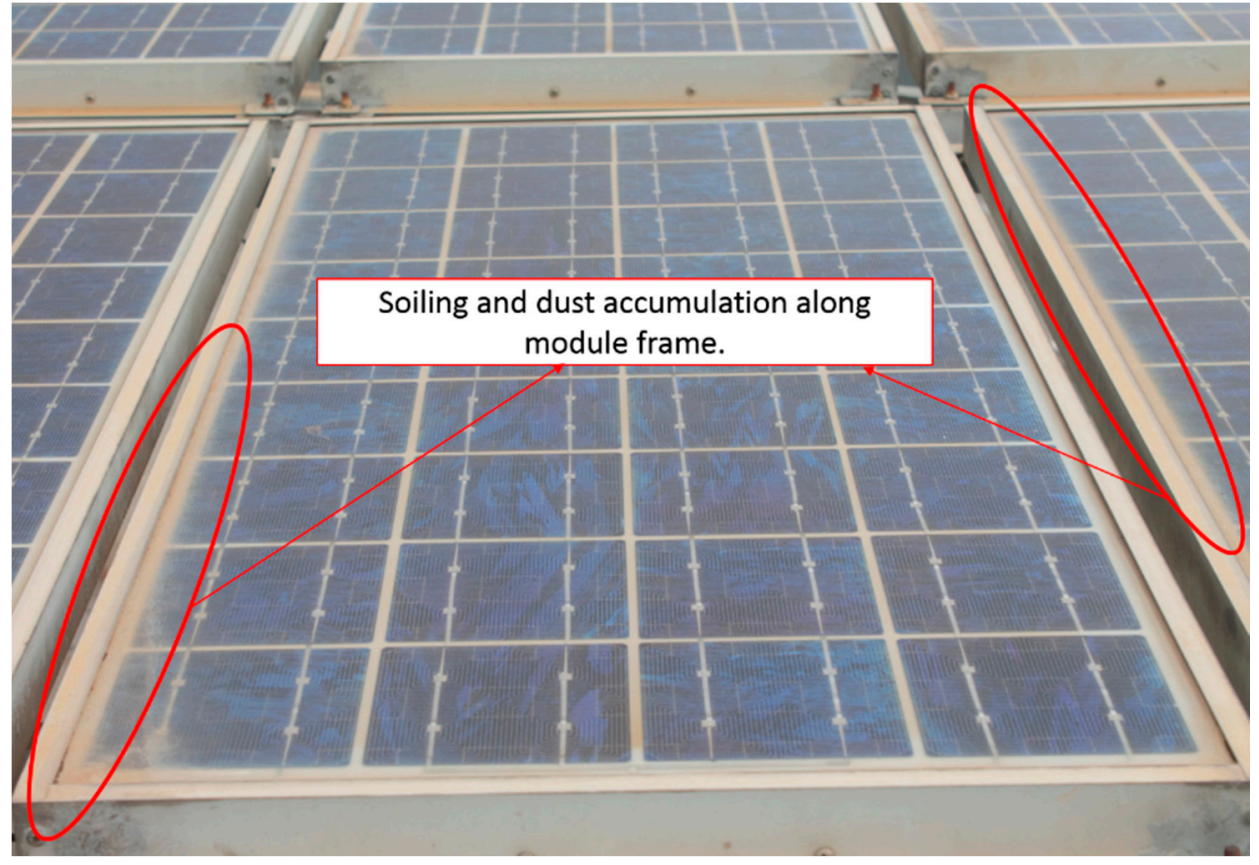

Figure 10. Soiling and dust accumulation along module frame.

\subsection{Performance Measurements (I-V Curve)}

Module temperatures during the measurements period ranged from $47.80^{\circ} \mathrm{C}$ to $58.90^{\circ} \mathrm{C}$, while the irradiance conditions varied from $883 \mathrm{~W} / \mathrm{m}^{2}$ to $1020 \mathrm{~W} / \mathrm{m}^{2}$. The raw data, showing the different irradiance and temperature values are shown in Table A1 (Appendix A). For each module, the measurements were repeated 5 times. The values were standardized (to STC) using Equations (2)-(5). The key parameters, with their associated random errors are shown in Figures 11-13.

\subsubsection{Peak Power}

Overall on module-by-module basis, the power output had declined from $49.5 \mathrm{~W}$ to $32.2-39 \mathrm{~W}$ (with a median of $37.6 \mathrm{~W}$ ) over the 19-year period of exposure (Figure 11). This represents a decline of $21.1 \%-35.0 \%$, with a median of $24 \%$. On an annual basis, the median degradation rate is $1.3 \%$. 
The advantage of using the median instead of the mean, is that, it minimizes the impact of outliers. Modules of this era (the 1990s) came with 10-year warranties; within which period $80 \%$ of the peak power was guaranteed [18]. This implied a maximum average annual degradation of $2 \%$ (see Figure 1 ).

Assuming a linear degradation rate for the modules, as suggested by [60], all the modules could be said to have met and exceeded warranty provisions. In addition, modules of the time came with tolerance of $\pm 10 \%$ [18]; which implied that the peak power less $10 \%$, (in this case $44.5 \mathrm{~W}$ ) would still be within the purchase agreement. If this lower limit of the tolerance were used, $80 \%$ of peak power will translate to $35.6 \mathrm{~W}$, in which case over $85 \%$ of the modules will still be operating above the minimum guaranteed output after 19 years of exposure. While some authors have defined module failure to mean an effect that degrades the module power, which is not reversed by normal operation or creates a safety issue [32], module life on the other hand, as noted by [30], does not lend itself to easy definition, as they could mean different things depending on the perspective. From a manufacturer's perspective, module life may be viewed in terms of financial liability period, whereas the user is not necessarily bound by this and may keep the module in service as long as it is safe, and meets or contributes to meeting their needs.

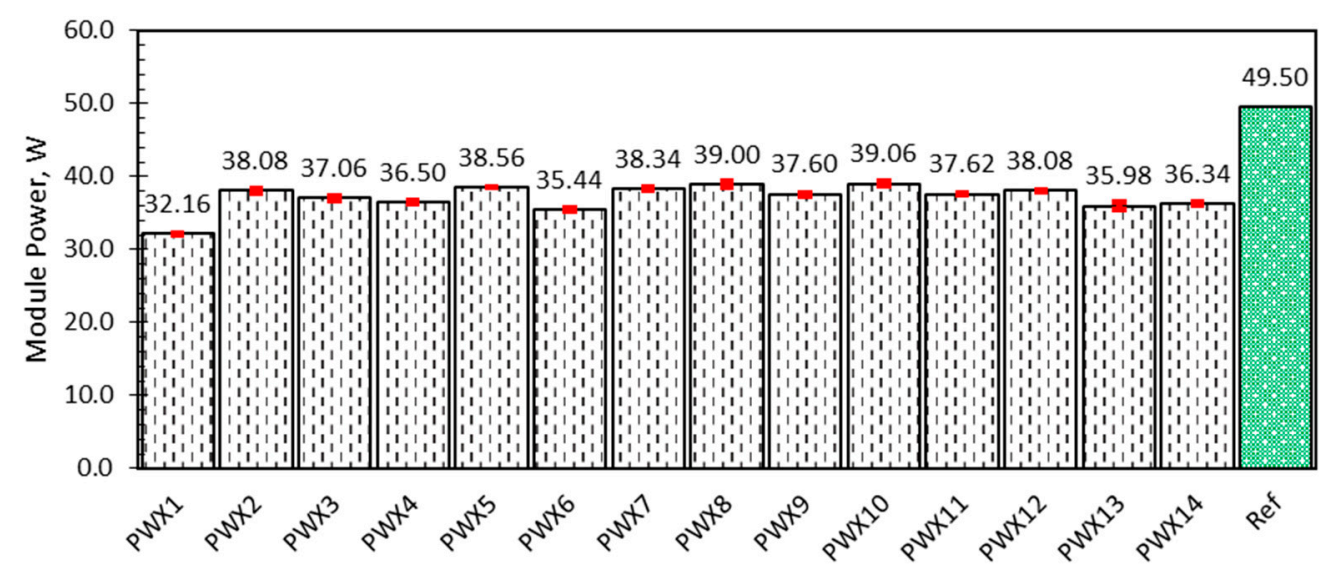

Figure 11. Peak power of modules at STC.

The coefficient of variation of the peak power of the 14 modules (computed as ratio of the population standard deviation to the mean) is 5\%; indicating uniformity of ageing. Such uniformity of ageing has been viewed by authors such as Skoczek et al. [41] as an indicator of good quality control in the module manufacturing process. The power loss in module PWX1 is notably much higher than the remaining modules. Its power output had dropped to $32.2 \mathrm{~W}$, much below the median value of $37.6 \mathrm{~W}$; registering a decline of $35 \%$ compared with the median decline of $24 \%$ for the entire system. The nature of the I-V curve (discussed later in Section 3.2.4) may help in explaining the cause of the performance decline. Since module peak power is a function of short-circuit current, open-circuit voltage and fill factor; changes in power output must be explainable in terms of these parameters.

\subsubsection{Short-Circuit Current}

As shown in Figure 12, the short-circuit current of the modules declined from $3.1 \mathrm{~A}$ to between $2.74 \mathrm{~A}$ and $2.92 \mathrm{~A}$, with a median value of $2.86 \mathrm{~A}$. These represent, respectively declines of $5.8 \%$ to $11.7 \%$ and median of $7.9 \%$ over the 19 -year period. On an annual basis, the median decline in the short-circuit current is $0.4 \%$. Of particular note is module PWX6 (Figure 12), which showed a much sharper decline in short circuit current $(0.6 \%$ /year). Bubble formation and delamination is suspected to be the cause of this observation. Overall, however, coefficient of variation was $2 \%$. The short circuit current has a strong dependence on irradiance and hence a decline in short-circuit current could be due to optical transmission problems caused by factors such as module soiling, browning/yellowing of encapsulant and delamination which causes optical decoupling (mismatch of refractive indices). 


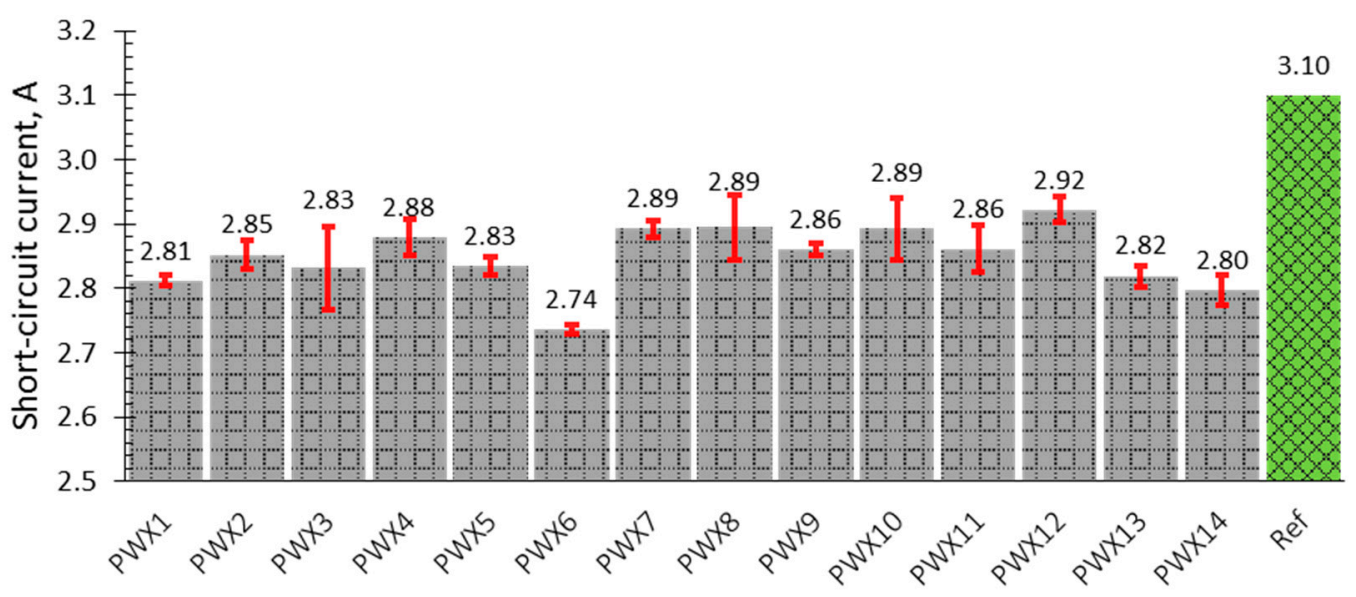

Figure 12. Short-circuit current of modules at STC.

\subsubsection{Open-Circuit Voltage}

The open-circuit voltage $\left(\mathrm{V}_{\mathrm{oc}}\right)$ of the modules (Figure 13) ranged from a low of $20.4 \mathrm{~V}$ (PWX 14) to $20.8 \mathrm{~V}$ (PWX 5) and a median of $20.7 \mathrm{~V}$. The decline from the nameplate rating of $21.6 \mathrm{~V}$ is $3.6 \%$ to $5.6 \%$ over the period with a median of $4.1 \%$. The annual decline translates to $0.2 \%$ to $0.3 \%$ with median of $0.2 \%$. The open-circuit voltage coefficient of variation is estimated as $1 \%$. The annual degradation rate of the open circuit voltage is significantly less than the short-circuit current. Loss of $\mathrm{V}_{\mathrm{oc}}$ usually attributed to degradation of the cells and shunting problems [43].

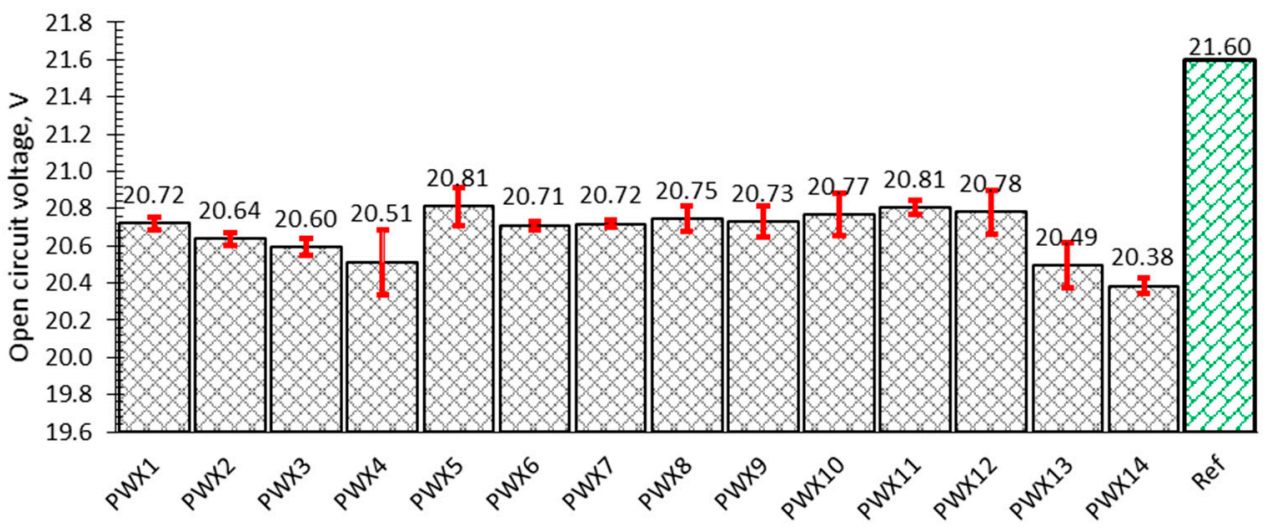

Figure 13. Open-circuit voltage of modules at STC.

\subsubsection{Fill Factor}

The fill factor of the modules (Figure 14) was in the range of 55\% (PWX 1) to 65.2\% (PWX 5). This represents a decline of $11.9 \%$ to $25.7 \%$ with a median of $14.3 \%$ over the period of exposure; compared with the original value of $74 \%$. On an annual basis, this translates to $0.6 \%-1.4 \%$ and median of $0.8 \%$. Even though the coefficient of variation of the fill factor of the modules is $4 \%$, module PWX 1 , exhibits markedly higher loss of fill factor compared with the rest of the modules. Figure 15, shows the I-V curves of the modules studied. The power loss of module PWX1 (Section 3.2.1), in particular, is traceable to fill factor loss. Loss of fill factor is generally attributed to increase in series resistance of the modules ([38,40]), arising from factors such as corrosion and thermo-mechanical fatigue of the solder bonds and interconnection. Indeed, the shape of the I-V curve arising from fill factor loss, as is the case with module PWX 1 (Figure 15), is reproducible from the 1-diode PV cell model by increasing the series resistance [61]. 


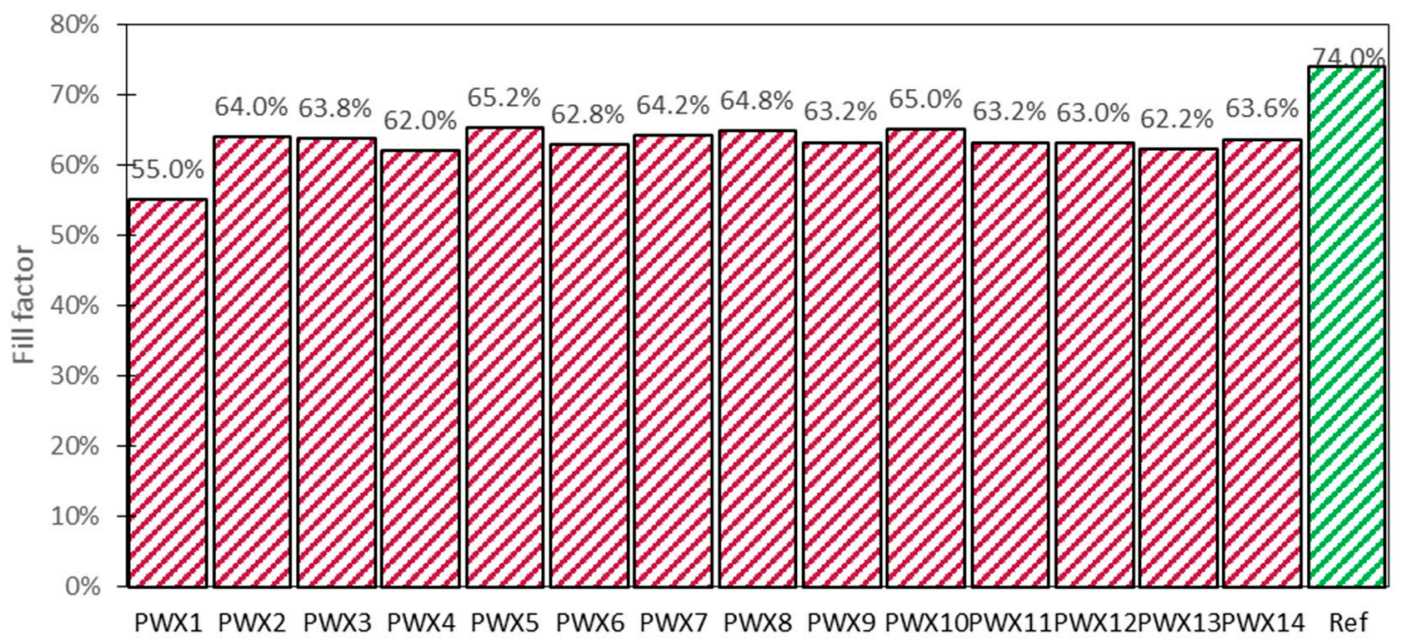

Figure 14. Fill factor of modules at STC.

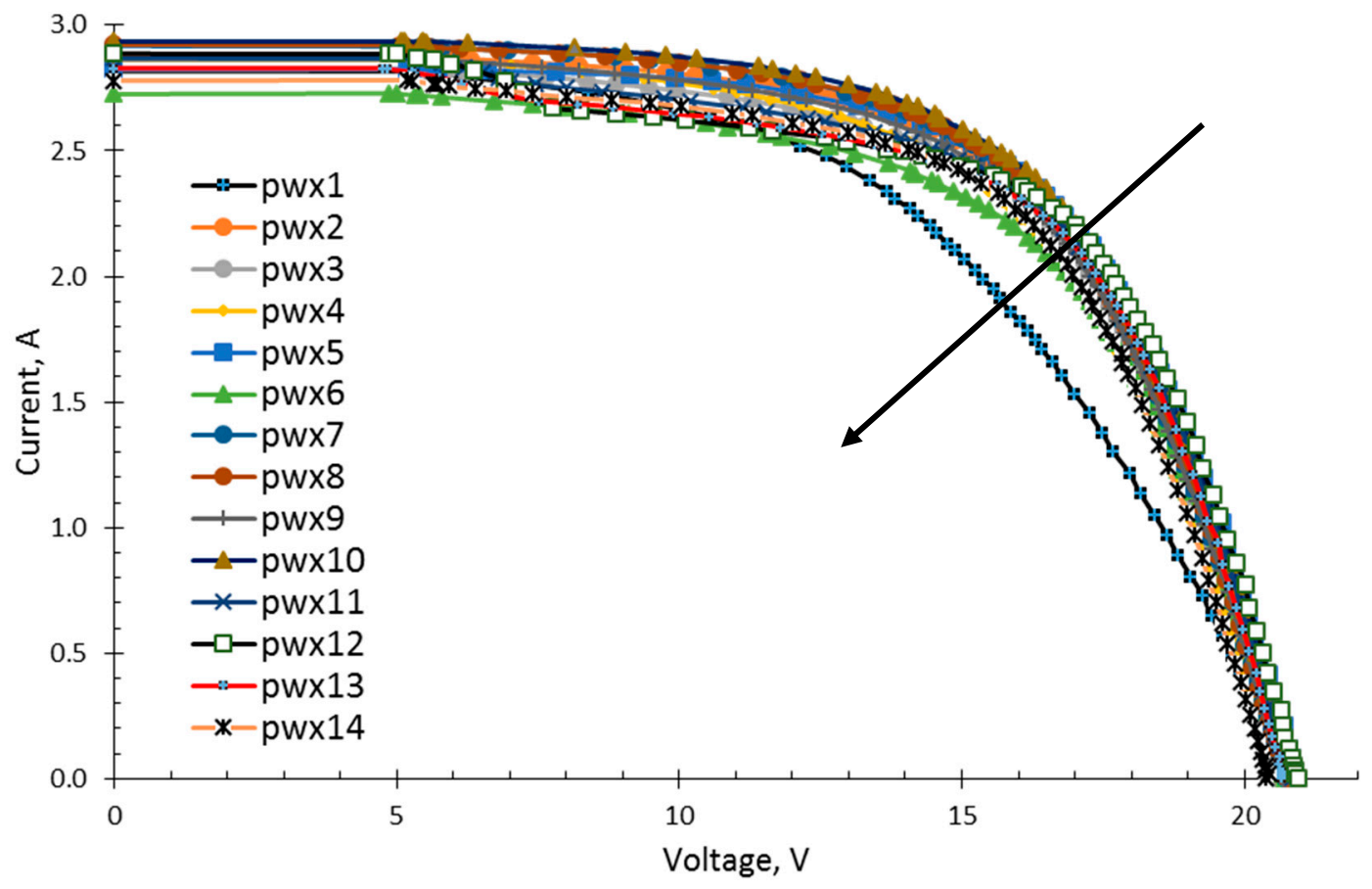

Figure 15. I-V curves of modules.

\subsection{Thermal Imaging}

Thermal imaging of the modules, forward-biased at $\mathrm{I}_{\mathrm{sc}}$, generally did not reveal much inhomogeneity in module surface temperature. Temperature distribution on the module surface showed difference of less than $5^{\circ} \mathrm{C}$ for most modules, the exception being module PWX 1 which had cell temperature difference of about $10{ }^{\circ} \mathrm{C}$ at some sections of the module (Figure 16).

The general uniformity of temperature distribution and non-occurrence of hot-spots agrees with the point made earlier on the uniform ageing of the modules based on the co-efficient of variation of peak power and other key performance parameters. 


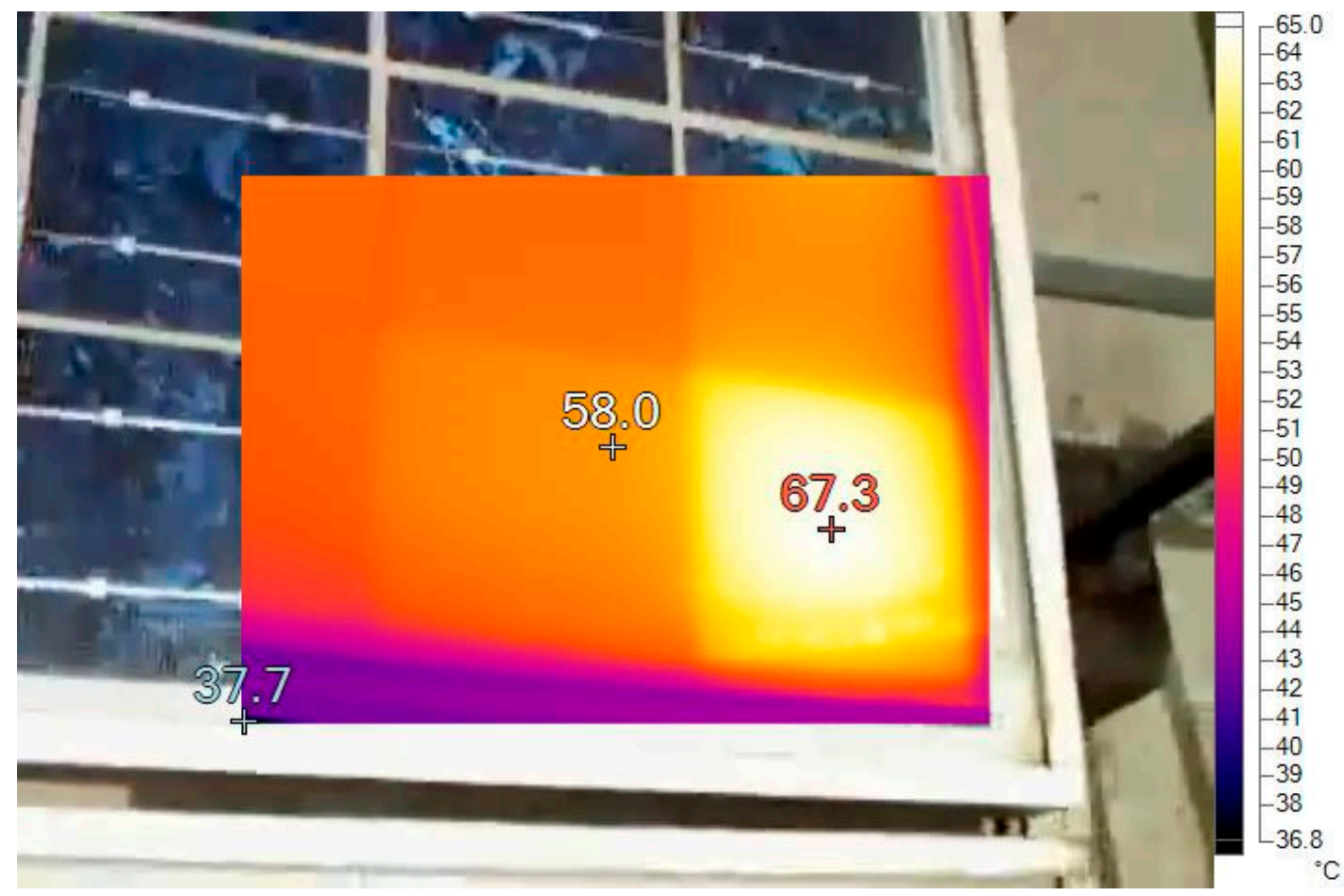

Figure 16. Surface temperature distribution-module PWX 1.

\subsection{Accounting for Power Loss}

As noted in Section 3.2.1, the peak power of the module is a function of short-circuit current, open-circuit voltage and fill factor. A plot of annual loss in peak power versus these parameters $\left(\mathrm{I}_{\mathrm{SC}}\right.$, $\mathrm{V}_{\mathrm{oc}}$ and FF) indicates that they are positively correlated (Figure 17).

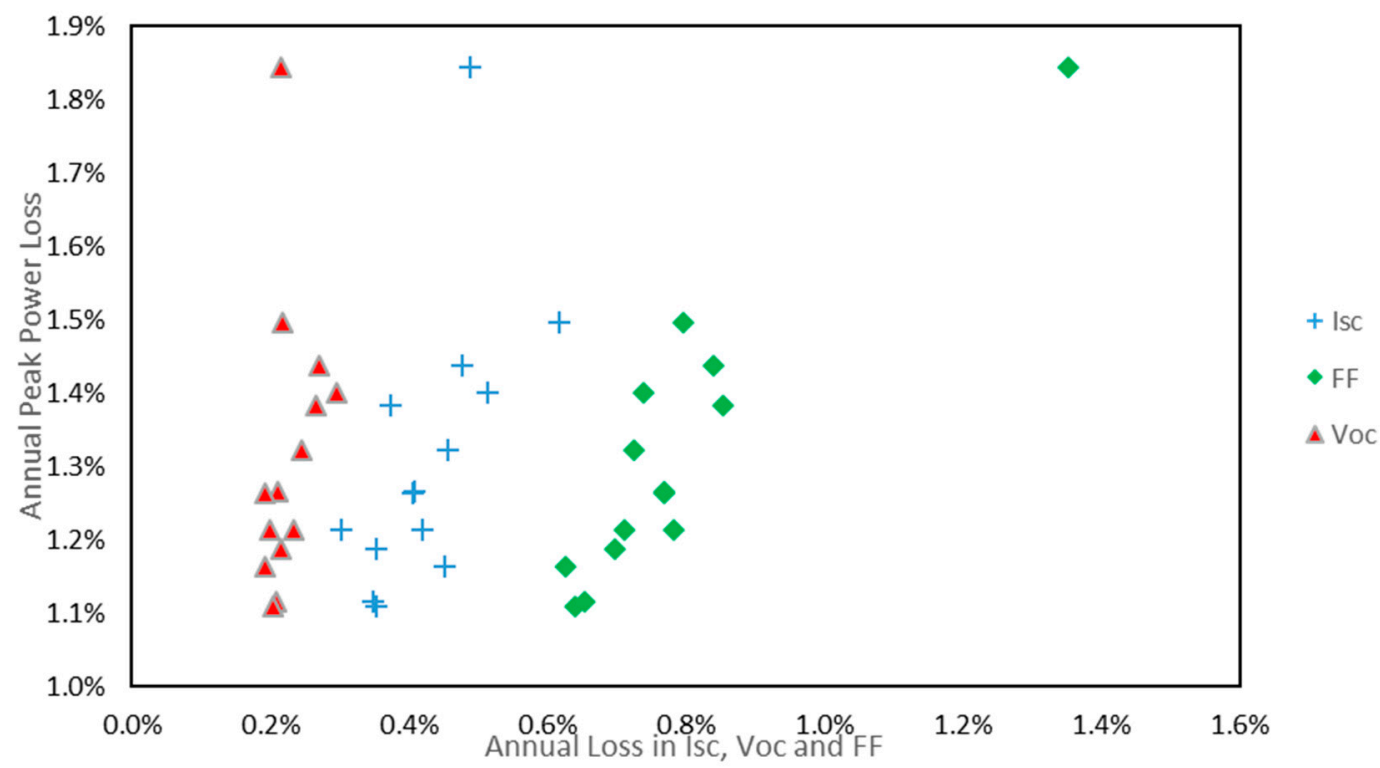

Figure 17. Annual power loss versus losses in $\mathrm{I}_{\mathrm{sc}}, \mathrm{V}_{\mathrm{oc}}$ and FF.

A regression analysis indicates that $\mathrm{I}_{\mathrm{sc}}$ and $\mathrm{FF}$, together explain $97.5 \%$ of the variability in peak power (adjusted R-squared), Table 3. The loss of power is therefore attributable to losses in short-circuit current and fill factor, and to a lesser extent, on the open circuit voltage. 
Table 3. Regression parameters ( $\mathrm{P}_{\text {nom }}$ modelled by Isc and FF).

\begin{tabular}{ccccc}
\hline & Coefficients & Standard Error & t Stat & $p$-value \\
\hline Intercept & 0.002495398 & 0.000502317 & 4.96778 & $4.24 \times 10^{-4}$ \\
I $_{\text {SC }}$ & 0.907725217 & 0.106155361 & 8.55091 & $3.45 \times 10^{-6}$ \\
FF & 0.869416269 & 0.050343898 & 17.26955 & $2.56 \times 10^{-9}$ \\
\hline
\end{tabular}

Adjusted R Square: 0.975; F statistic: 256.2 Standard error: 0.000308;

\subsection{General Discussion}

To put the current results into perspective, it is helpful to compare with similar studies. Jordan and Kurtz [18], conducting an analytical review of alomost 2000 reported degradation rates found in the literature, determined a median value of $0.61 \%$ /year degradation for multicrystalline Silicon modules installed prior to the year 2000, a total of 409 installations. In a more recent and updated work by an expanded team, Jordan et al. [60], based on a literature review, found that a median annual degradation rate of $0.6 \%$ (based on 683 observations) was reported for crystalline silicon modules installed in hot humid climates. Even though the median degradation (peak power) of the modules in this present study is higher (1.3\%/year) than the median of reported in these reviews, it is consistent with rates reported of installations in the period 1990-2000, which were about 1\%/year [60]. It should be noted also, that, the data used in the reviews do not have balanced geographical representation as acknowledged by the authors of the review. This geographical imbalance underscores the need for continuing effort to study systems that are installed in regions for which data is under-reported or not reported at all.

The dominance of short-circuit current and fill factor in driving the power loss of the modules is consistent with previous studies which have reported on this, including: Ndiaye et al. [38], Bandou et al. [37] and Jordan and Kurtz [18]. Bandou et al. [37] studied a 28-year old systen installed in the desert of Algeria and reported annual degradation of $1.22 \%$ in peak power, arising mainly from $0.78 \%$ in short circuit current and $0.56 \%$ in fill factor. Even though the study by Ndiaye et al. [38] had a rather short observation period (1.3-4 years), the results also confirm the dominance of short-circuit current and fill factor in power degradation.

\section{Concluding Remarks}

This study has examined the performance of fourteen (14) polysilicon modules, installed at KNUST in Kumasi Ghana, a hot and humid climate, after 19 years of outdoor exposure and under load. Systematic visual inspection, electrical characterization using current-voltage (I-V) tracing and thermal imaging were used to assess the modules. This paper concludes as follows:

- The physical condition of the modules was good, with no major visually observable defects on the front glass, back sheets, wires/connectors, junction box, frame and metallization. Some bubble on front side and minor discolouration at the edge of some cells were however observed upon magnification of images acquired.

- During the period of exposure (19 years), the median decline recorded in the performance parameters of the modules, compared with reference values were, respectively: Peak Power $\left(P_{n o m}\right)-24 \%$, Short Circuit Current $\left(I_{s c}\right)-7.9 \%$, Open Circuit Voltage $\left(V_{o c}\right)-4.1 \%$ and Fill Factor (FF) $-14.3 \%$.

- On an annual basis, the median of the decline in performance parameters were: $P_{\text {nom }}-1.3 \%$, $I_{s c}-0.4 \%, V_{o c}-0.2 \%$ and $F F-0.8 \%$.

- The module had a warranty of 10 years, with a tolerance of $\pm 10 \%$. At the median annual power degradation rate of $1.3 \%$, the module has met and exceeded warranty expectations, even if the lower end of the tolerance was ignored.

- The reduction in nominal power is dominated by reduction in fill factor and short circuit current. 
To contribute to filling the data gap on long-term PV module performance degradation in Ghana, future work will study modules installed in various micro-climatic zones of Ghana.

Acknowledgments: David A Quansah is grateful to the Quota Scholarship Programme of the Norwegian Government for sponsoring his Doctoral studies at NMBU Norway. He is also grateful to his employer, the Kwame Nkrumah University of Science and Technology (KNUST) for granting him study leave and equipment support. The authors are grateful to the Provost of the College of Engineering at KNUST for providing financial assistance towards data collection, and also to Research Assistants at The Brew-Hammond Energy Centre (Jacob and Henry) for their support during the measurements period.

Author Contributions: David A. Quansah, Muyiwa S Adaramola and G Takyi conceived and designed the experiments and developed the outline of the paper. David A. Quansah (with assistance of Isaac A. Edwin) conducted the measurements. Isaac A. Edwin contributed to the system description and provided the background to the installation. David A. Quansah did the analysis of the data and generated the first draft of the manuscript. All co-authors contributed review comments to the manuscript.

Conflicts of Interest: The authors declare no conflict of interest.

\section{Appendix A}

Table A1. Measured performance data at various irradiance and temperature (irradiance nearest $1000 \mathrm{~W} / \mathrm{m}^{2}$ ).

\begin{tabular}{ccccccccc}
\hline Module ID & T $_{\text { mod, }}{ }^{\circ} \mathbf{C}$ & $\mathbf{G}, \mathbf{W} / \mathbf{m}^{\mathbf{2}}$ & $\mathbf{I}_{\mathbf{s c}}[\mathbf{A}]$ & $\mathbf{V}_{\mathbf{~ o c}}[\mathbf{V}]$ & $\mathbf{I m p p}[\mathbf{A}]$ & $\mathbf{U m p p}[\mathbf{V}]$ & $\mathbf{P}[\mathbf{W}]$ & $\mathbf{F F}$ \\
\hline PWX1 & 56.70 & 970.00 & 2.73 & 18.33 & 2.18 & 11.86 & 25.80 & 0.51 \\
PWX2 & 58.80 & 937.00 & 2.69 & 18.14 & 2.25 & 13.34 & 30.00 & 0.61 \\
PWX3 & 58.90 & 941.00 & 2.67 & 18.02 & 2.15 & 13.53 & 29.10 & 0.60 \\
PWX4 & 58.90 & 949.00 & 2.72 & 18.10 & 2.25 & 12.83 & 28.80 & 0.59 \\
PWX5 & 54.10 & 997.00 & 2.83 & 18.73 & 2.39 & 13.88 & 33.20 & 0.63 \\
PWX6 & 50.10 & 1014.00 & 2.76 & 18.84 & 2.26 & 13.91 & 31.40 & 0.60 \\
PWX7 & 51.10 & 958.00 & 2.79 & 18.73 & 2.30 & 14.01 & 32.20 & 0.61 \\
PWX8 & 51.40 & 958.00 & 2.81 & 18.73 & 2.37 & 13.61 & 32.20 & 0.61 \\
PWX9 & 57.40 & 960.00 & 2.74 & 18.27 & 2.22 & 13.74 & 30.40 & 0.61 \\
PWX10 & 51.50 & 883.00 & 2.59 & 18.73 & 2.14 & 14.01 & 30.00 & 0.62 \\
PWX11 & 57.30 & 964.00 & 2.76 & 18.42 & 2.25 & 13.67 & 30.70 & 0.60 \\
PWX12 & 49.10 & 917.00 & 2.65 & 19.03 & 2.06 & 14.87 & 30.60 & 0.61 \\
PWX13 & 47.80 & 962.00 & 2.71 & 18.90 & 2.22 & 14.28 & 31.70 & 0.62 \\
PWX14 & 55.40 & 1020.00 & 2.81 & 18.19 & 2.38 & 13.46 & 32.00 & 0.63 \\
\hline
\end{tabular}

\section{References}

1. IEA. Projected Costs of Generating Electricity 2015 Edition; IEA: Paris, France, 2015.

2. IEA. Technology Roadmap: Solar Photovoltaic Energy 2014 edition; OECD/IEA: Paris, France, 2014.

3. IEA. World Energy Outlook; OECD/IEA: Paris, France, 2013.

4. IRENA. Africa 2030: Roadmap for a Renewable Energy Future; IRENA: Masdar City, United Arab Emirates, 2015.

5. IRENA. Solar PV in Africa: Costs and Markets; IRENA: Masdar City, United Arab Emirates, 2016.

6. REN21. ECOWAS Renewable Energy and Energy Efficiency Status Report; ECREEE/UNIDO/REN21: Paris, France, 2014.

7. REN21. Renewables 2015 Global Status Report; REN21 Secretariat: Paris, France, 2015.

8. REN21. Renewables 2016 Global Status Report; REN21 Secretariat: Paris, France, 2016.

9. Fraunhofer ISE. Photovoltaics Report; Fraunhofer ISE: Freiburg, Germany, 2015.

10. NREL. Best Research Cell Efficiencies; NREL: Golden, CO, USA, 2016.

11. Yoshikawa, K.; Kawasaki, H.; Yoshida, W.; Irie, T.; Konishi, K.; Nakano, K.; Uto, T.; Adachi, D.; Kanematsu, M.; Uzu, H.; et al. Silicon heterojunction solar cell with interdigitated back contacts for a photoconversion efficiency over 26\%. Nat. Energy 2017, 2, 17032. [CrossRef]

12. Solar Cell Efficiency Detailed Balance. Available online: http://www.pveducation.org/pvcdrom/detailedbalance (accessed on 16 May 2017).

13. Shockley, W.; Queisser, H.J. Detailed Balance Limit of Efficiency of p-n Junction Solar Cells. J. Appl. Phys. 1961, 32, 510. [CrossRef]

14. ITRPV/VDMA. International Technology Roadmap for Photovoltaic 2015 Results; ITRPV/VDMA: Frankfurt, Germany, 2016. 
15. Yang, G. Life Cycle Reliability Engineering; John Wiley \& Sons: Hoboken, NJ, USA, 2007.

16. ReliaSoft Corporation. About Reliability Engineering. 2016. Available online: http://www.weibull.com/ basics/reliability.htm. (accessed on 18 May 2017).

17. Verma, A.K.; Ajit, S.; Karanki, D.R. Reliability and Safety Engineering; Springer: London, UK, 2016.

18. Jordan, D.C.; Kurtz, S.R. Photovoltaic Degradation Rates-an Analytical Review. Prog. Photovolt. Res. Appl. 2013, 21, 12-29. [CrossRef]

19. EnergySage Inc. What to Know About a Solar Panel Warranty; EnergySage Inc.: Boston, MA, USA, 2015.

20. REC Solar. 25-year Linear Power Output Warranty. Available online: http://www.recgroup.com/sites/ default/files/documents/rec_fact_sheet_warranty_web_en_20130719.pdf (accessed on 16 May 2017).

21. King, D.L.; Quintana, M.A.; Kratochvil, J.A.; Ellibee, D.E.; Hansen, B.R. Photovoltaic module performance and durability following long-term field exposure. AIP Conf. Proc. 1999, 462, 565-571.

22. Srinivasan, S. Solar photovoltaics: Oligopsony, non-market decision-making and the paradoxical persistence of unprofitability. Int. J. Green Econ. 2013, 7, 116-147. [CrossRef]

23. GTM Research. Rest in Peace: The List of Deceased Solar Companies. Available online: http:/ / www.greentechmedia.com/articles/read/Rest-in-Peace-The-List-of-Deceased-Solar-Companies? utm_source=Daily\&utm_medium=Headline\&utm_campaign=GTMDaily (accessed 18 May 2017).

24. CivicSolar Inc. Canadian Solar Warranty Insurance. Available online: http://investors.canadiansolar.com/ phoenix.zhtml?c=196781\&p=irol-newsArticle\&ID=1695334 (accessed on 18 May 2017).

25. CSUN. 25-Year Insurance Backed Warranty. Available online: http://www.csun-solar.com/fileadmin/ dateiablage/documents/PowerGuard_CSUN_2014_Flyer.pdf (accessed on 18 May 2017).

26. Trina Solar. 25 Year Insurance Backed Warranty. Available online: https:/ / es-media-prod.s3.amazonaws. com/media/u/bad/9e9/d9b/4a377fac554a5266604e7b20285d4e78/TrinaSolar_Warranty.pdf (accessed on 18 May 2017).

27. Canadian Solar (USA) Inc. PV Module Warranty and Warranty Insurance Comparisons: A Cornerstone of Bankability. Available online: http:/ /www.solarsouthwestflorida.com/wp-content/uploads/2012/01/ PV-Module-Warranty-and-Warranty-Insurance-Comparisons-White-Paper-Sept.-2011.pdf (accessed on 18 May 2017).

28. IEC. Crystalline Silicon Terrestrial Photovoltaic (PV) Modules-Design Qualification and Type Approval. Available online: https:/ / webstore.iec.ch/publication/4928 (accessed on 18 May 2017).

29. IEC. Thin-Film Terrestrial Photovoltaic (PV) Modules-Design Qualification and Type Approval; IEC: Geneva, Switzerland, 2008.

30. Osterwald, C.R.; McMahon, T.J. History of Accelerated and Qualification Testing of Terrestrial Photovoltaic Modules: A Literature Review. Prog. Photovolt. Res. Appl. 2009, 17, 11-33. [CrossRef]

31. Zielnik, A.F.; Dumbleton, D.P. Photovoltaic Module Weather Durability \& Reliability—Will my module last outdoors? Available online: https:/ /us.sunpower.com/sites/sunpower/files/media-library/white-papers/ wp-atlas-25-plus-photovoltaic-module-weather-durability-reliability.pdf (accessed on 16 May 2017).

32. IEA. Review of Failures of Photovoltaic Modules; OECD/IEA: Paris, France, 2014.

33. Fraunhofer ISE. Photovoltaics Report; Fraunhofer ISE: Freiburg, Germany, 2016.

34. ITRPV/VDMA. International Technology Roadmap for Photovoltaic; ITRPV/VDMA: Frankfurt, Germany, 2015.

35. Rudolph, D.; Olibet, S.; Hoornstra, J.; Weeber, A.; Cabrera, E.; Carr, A.; Koppes, M.; Kopecek, R. Replacement of silver in silicon solar cell metallization pastes containing a highly reactive glass frit: Is it possible? Energy Proced. 2013, 43, 44-53. [CrossRef]

36. Lorenzo, E.; Zilles, R.; Moretón, R.; Gómez, T.; de Olcoz, A.M. Performance analysis of a 7-kW crystalline silicon generator after 17 years of operation in Madrid. Prog. Photovolt. Res. Appl. 2014, 22, 1273-1279. [CrossRef]

37. Bandou, F.; Arab, A.H.; Belkaid, M.S.; Logerais, P.-O.; Riou, O.; Charki, A. Evaluation performance of photovoltaic modules after a long time operation in Saharan environment. Int. J. Hydrog. Energy 2015, 40, 13839-13848. [CrossRef]

38. Ndiaye, A.; Kébé, C.M.F.; Charki, A.; Ndiaye, P.A.; Sambou, V.; Kobi, A. Degradation evaluation of crystalline-silicon photovoltaic modules after a few operation years in a tropical environment. Sol. Energy 2014, 103, 70-77. [CrossRef] 
39. Quintana, M.A.; King, D.L.; McMahon, T.J.; Osterwald, C.R. Commonly Observed Degradation in Field-Aged Photovoltaic Modules. Proceedings of Conference Record of the Twenty-Ninth IEEE Photovoltaic Specialists Conference, New Orleans, LA, USA, 19-24 May 2002; pp. 1436-1439.

40. Skoczek, A. Long-term performance of photovoltaic modules. Available online: http://www.solar-academy. com/menuis/longtermperformanceofpvsystems032725.pdf (accessed on 16 May 2017).

41. Skoczek, A.; Sample, T.; Dunlop, E.D. The results of performance measurements of field-aged crystalline silicon photovoltaic modules. Prog. Photovolt. Res. Appl. 2009, 17, 227-240. [CrossRef]

42. Kahoul, N.; Houabes, M.; Sadok, M. Assessing the early degradation of photovoltaic modules performance in the saharan region. Energy Convers. Manag. 2014, 82, 320-326. [CrossRef]

43. Ferrara, C.; Philipp, D. Why Do PV Modules Fail? Energy Proced. 2012, 15, 379-387. [CrossRef]

44. Jordan, D.C.; Wohlgemuth, J.H.; Kurtz, S.R. Technology and Climate Trends in PV Module Degradation. Proceedings of 27th European Photovoltaic Solar Energy Conference and Exhibition, Frankfurt, Germany, 24-28 September 2012.

45. Phinikarides, A.; Kindyni, N.; Makrides, G.; Georghiou, G.E. Review of photovoltaic degradation rate methodologies. Renew. Sustain. Energy Rev. 2014, 40, 143-152. [CrossRef]

46. Peel, M.C.; Finlayson, B.L.; Mcmahon, T.A. Updated world map of the köppen-geiger climate classification. Hydrol. Earth Syst. Sci. Discuss. 2007, 4, 439-473. [CrossRef]

47. FAO. Ghana-Country Pasture/Forage Resource Profiles. Available online: http://www.fao.org/ag/agp/ agpc/doc/counprof/ghana/Ghana.htm\#3.\%20CLIMATE\%20AND\%20AGRO-ECOLOGICAL\%20ZONES (accessed on 21 November 2016).

48. All-India Survey of Photovoltaic Module Degradation: 2013. Available online: http://www.ncpre.iitb.ac.in/ research/pdf/All_India_Survey_of_Photovoltaic_Module_Degradation_2013.pdf (accessed on 16 May 2017).

49. RETScreen International. RETScreen Clean Energy Project Analysis Software (Version 4.1) Climate Database. Available online: http://www.nrcan.gc.ca/energy/software-tools/7465 (accessed on 18 May 2017).

50. Nkrumah, F.; Klutse, N.A.B.; Adukpo, D.C.; Owusu, K.; Quagraine, K.A.; Owusu, A.; Gutowski, W. Rainfall variability over ghana: Model versus rain gauge observation. Int. J. Geosci. 2014, 5, 11. [CrossRef]

51. PVsyst SA; Version 5.74; PVSyst Photovoltaic Software: Satigny, Switzerland, 2012.

52. Field Applications for I-V Curve Tracers. Available online: http://solarprofessional.com/articles/designinstallation/field-applications-for-i-v-curve-tracers (accessed on 16 May 2017).

53. Current-Voltage Translation Procedure for PV Generators in the German 1,000 Roofs-Programme. Available online: http:/ / citeseerx.ist.psu.edu/viewdoc/download?doi=10.1.1.475.4370\&rep=rep1\&type= pdf (accessed on 16 May 2017).

54. Zaaiman, W. Solar Irradiance and Photovoltaic Measurements from Solar Radiation to PV Arrays. Proceedings of AFRETEP 3rd Regional Workshop, Cape Town, South Africa, 20-24 February 2012.

55. IEC. IEC 60891:2009 Photovoltaic devices_Procedures for Temperature and Irradiance Corrections to Measured I-V Characteristics; IEC: Geneva, Switzerland, 2009.

56. Outdoor PV Module Degradation of Current-Voltage Parameters. 2012. Available online: http://www.nrel. gov/docs/fy12osti/53713.pdf (accessed on 16 May 2017).

57. Tsuno, Y.; Hishikawa, Y.; Kurokawa, K. Modeling I-V Curves of PV Modules Using Interpolation/Extrapolation. Sol. Energy Mater. Sol. Cell. 2009, 93, 1070-1073. [CrossRef]

58. Marion, B. A method for modeling the current-voltage curve of a PV module for outdoor conditions. Prog. Photovolt. Res. Appl. 2002, 10, 205-214. [CrossRef]

59. Anderson, J.A. Photovoltaic Translation Equations: A New Approach; NREL: Golden, CO, USA, 1996.

60. Jordan, D.C.; Kurtz, S.R.; VanSant, K.; Newmiller, J. Compendium of photovoltaic degradation rates. Prog. Photovolt. Res. Appl. 2016, 24, 978-989. [CrossRef]

61. Effect of parasitic Resistances- Series Resistance. Available online: http://www.pveducation.org/pvcdrom/ series-resistance (accessed on 5 December 2016).

(C) 2017 by the authors. Licensee MDPI, Basel, Switzerland. This article is an open access article distributed under the terms and conditions of the Creative Commons Attribution (CC BY) license (http:/ / creativecommons.org/licenses/by/4.0/). 